\title{
Important crustal growth in the Phanerozoic: Isotopic evidence of granitoids from east-central Asia
}

\author{
BOR-MING JAHN ${ }^{1}$, FUYUAN WU ${ }^{1,2}$ and DAWEI HONG ${ }^{3}$ \\ ${ }^{1}$ Géosciences Rennes, Université de Rennes 1, 35042 Rennes Cedex, France \\ email: jahn@univ-rennes1.fr \\ ${ }^{2}$ Department of Geology, Changchun University of Science and Technology, Changchun 130 061, China \\ ${ }^{3}$ Lithosphere Research Centre, CAGS, Beijing 100 037, China
}

The growth of the continental crust is generally believed to have been essentially completed in the Precambrian, and the amount of juvenile crust produced in the Phanerozoic is considered insignificant. Such idea of negligible growth in the Phanerozoic is now challenged by the revelation of very large volume of juvenile crust produced in the period of 500 to $100 \mathrm{Ma}$ in several orogenic belts. While appreciable volumes of juvenile terranes in North America (Canadian Cordillera, Sierra Nevada and Peninsular Range, Appalachians) have been documented based on Nd isotopic data, the mass of new crust formed in the East-Central Asian Orogenic Belt (ECAOB), eastern part of the Altaid Tectonic Collage, appears to be much greater than the above terranes combined. New and published Nd-Sr isotope data indicate that the Phanerozoic granitoids from the southern belt of the ECAOB (Xinjiang-West Mongolia-Inner Mongolia-NE China) as well as from Mongolia and Transbaikalia were generated from sources dominated by a depleted mantle component. These granitoids represent a significant growth of juvenile crust in the Phanerozoic.

Although most plutons in this huge orogenic belt belong to the calc-alkaline series, the ECAOB is also characterized by the emplacement of voluminous A-type granites. The origin of these rocks is probably multiple and is still widely debated. However, the isotopic data (Sr-Nd-O) and trace element abundance patterns of A-type granites from the ECAOB clearly indicate their mantle origin.

The evolution of the ECAOB and the entire Altaid Collage is most likely related to successive accretion of arc complexes. However, the emplacement of a large volume of post-tectonic A-type granites requires another mechanism-probably through a series of processes including underplating of massive basaltic magma, partial melting of these basic rocks to produce granitic liquids, followed by extensive fractional crystallization. The proportion of juvenile to recycled, as well as that of arc-related to plume-generated, continental crust remains to be evaluated by more systematic dating and isotope tracer studies.

\section{Introduction}

The terrestrial continental crust is a unique feature among the planets in the solar system. Its formation and evolution is undoubtedly one of the most important subjects of research and debate in earth science. Two major hypotheses have been proposed to explain the evolution of the continental crust. The first proposes that the present mass of the crust was formed very early in the earth history and has been recycled through the mantle in steadily decreasing fashion such that new additions are balanced by losses, resulting in a steady state system (Armstrong 1968, 1981, 1991). The second proposes that the crust grew throughout geological time, with a rapid growth rate in early (Reymer and Schubert 1984, 1986) or in late Archean (Taylor and McLennan 1985, 1995), followed by a diminished rate afterwards. Other hypotheses suggest rates of crustal growth in between the two extremes. Whether or not the continental

Keywords. Crustal evolution; granites; Phanerozoic; Sr-Nd isotopes; east-central Asia. 
mass has been added in an episodic or continuous fashion (Moorbath 1978; Stein and Hofmann 1994) is another issue of debate. In all cases, the amounts of new continental material or juvenile crust formed in the Phanerozoic, and especially in the last $250 \mathrm{Ma}$, have been considered to be very minor or insignificant. However, this scenario has undergone revision in the last decade through studies of the Canadian Cordillera (Samson et al 1989) and east-central Asia.

In east-central Asia, very large volumes of granitic rocks of late Paleozoic to Mesozoic ages were emplaced in the East Central Asian Orogenic Belt (ECAOB), bounded by the Siberian and Sino-Korean cratons (figure 1). The ECAOB and orogenic belts to the west

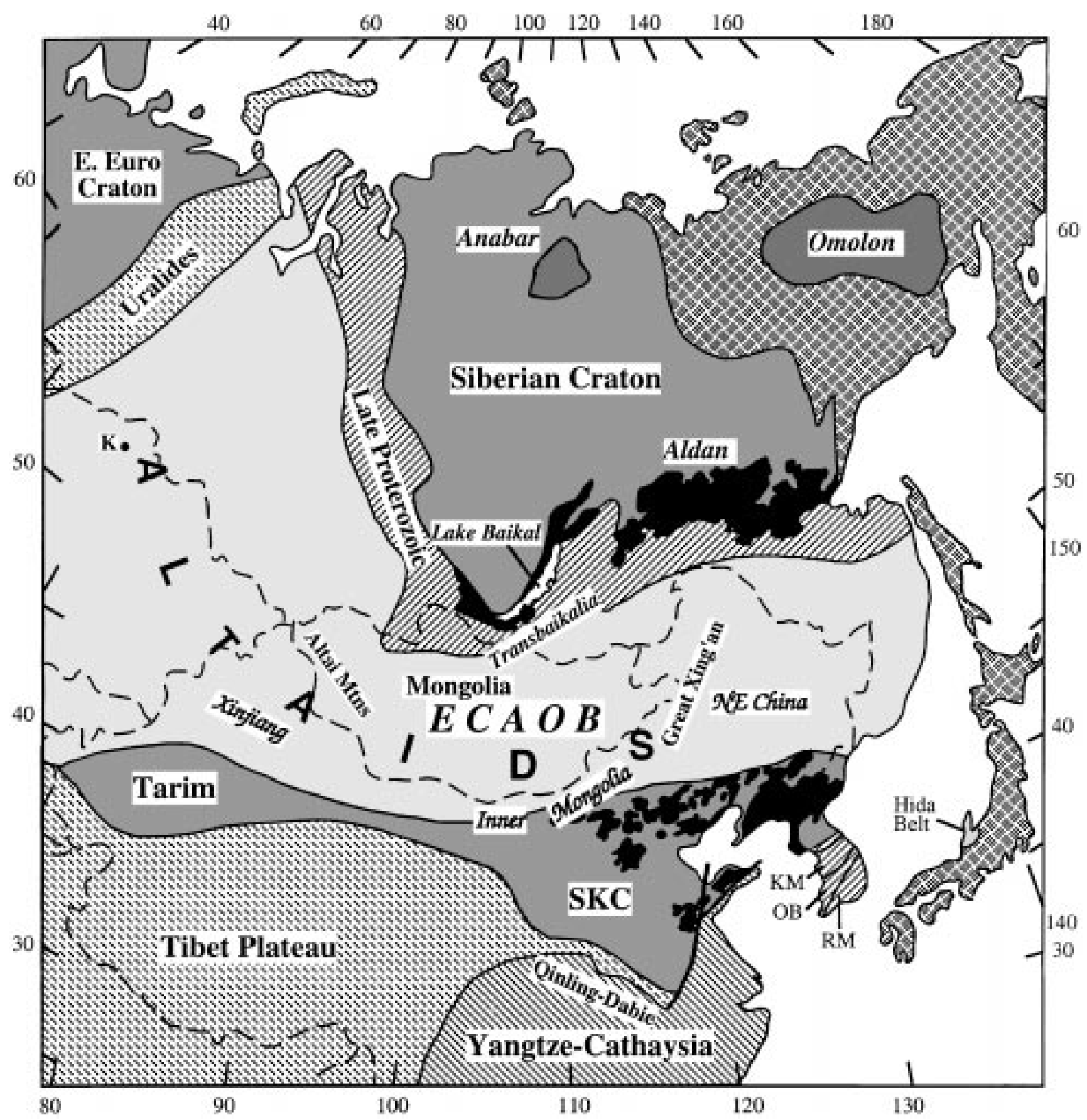

Figure 1. Simplified tectonic divisions of Asia. The East Central Asian Orogenic Belt (ECAOB), equivalent to the eastern part of the Altaid Tectonic Collage (Sengör et al 1993), is situated between two major Precambrian cratons: Siberian in the north and Sino-Korean (SKC)-Tarim in the south. Black areas are exposed Archean to early Proterozoic rocks. Crossed pattern on the righthand side including Japan represents Pacific fold belts. The Hida Belt of Japan may belong tectonically to the ECAOB. Abbreviations: $\mathrm{K}=$ Kokchetav (in northern Kazakhstan); $\mathrm{KM}=$ Kyonggi Massif, $\mathrm{OB}=$ Ogchon Belt, $\mathrm{RM}=\mathrm{Ryongnam}$ Massif (all in Korea). 
of it and up to the Ural Mountains have been collectively called Altaid Tectonic Collage (Sengör et al 1993; Sengör and Natal'in 1996). The Altaid Collage is different from the classical collisional orogens, such as the Alpine, Himalayan, Hercynian and Caledonian belts. According to Sengör and his collaborators (Sengör et al 1993; Sengör and Natal'in 1996), it was formed by accretion of arc complexes produced in subduction zones, and is characterized by the emplacement of immense volumes of granitic magmas and the general absence of nappe complexes imbricating older continental crust. However, the statement on the general absence of nappe complexes has been challenged by subsequent works, particularly in Kazakhstan (e.g., Gruschka et al 1997).

In the ECAOB, two gigantic belts of alkaline syenites and granites may be recognized: (1) a northern belt from northern Mongolia to Transbaikalia, and (2) a southern belt from Xinjiang (western China) through southern Mongolia to NE China (Manchuria). According to recent publications, more than 350 distinct granitic plutons are exposed in northern Mongolia and Transbaikalia and occupy a total area $\geq 500,000 \mathrm{~km}^{2}$ (Zanvilevich et al 1995; Wickham et al $1995,1996)$. In NE China, several hundred granitic bodies have been identified and constitute an area of $\approx 100,000 \mathrm{~km}^{2}$. Numerous granitic bodies also occur in northern Xinjiang and western Mongolia (Altai Mountains). Undoubtedly, this orogenic belt contains the most voluminous young granitic intrusions in the world. However, the precise time of the emplacement and origin of these granitoids, as well as their geodynamic significance in the context of Phanerozoic continental evolution are still poorly known and remain among the most pressing questions of crustal evolution to be answered.

These granitoids and related rocks of the ECAOB have been poorly studied and received little attention in the western geological literature until recently (Sengör et al 1993; Zanvilevich et al 1995; Sengör and Natal'in 1996; Wickham et al 1995, 1996; Kovalenko etal 1996; Hong etal 1995, 1996; Han etal 1997). Published results and our unpublished geochemical and $\mathrm{Sr}-\mathrm{Nd}$ isotope data on granites from the southern belt (Northern Xinjiang, Inner Mongolia and NE China) and from Mongolia to Transbaikalia indicate that most of the magmatic activities took place in the last $300 \mathrm{Ma}$, and that the rocks were formed from "juvenile" materials with significant amounts of upper mantle component.

In addition to the $\mathrm{Nd}$ isotopic evidence, oxygen isotope analyses of alteration-resistant titanites from granites of Transbaikalia (Wickham et al 1995, 1996) show a progressive decrease in $\delta^{18} \mathrm{O}$ of titanite (sphene) from $+6.5 \%$ in the earliest suite $(\approx 450 \mathrm{Ma})$ to $+1.5 \%$ in the youngest suite $(\approx 220 \mathrm{Ma})$. This corresponds to a decrease in whole-rock $\delta^{18} \mathrm{O}$ from $+11 \%$ o to $+6 \%$. It appears that whereas the older magmas with higher $\delta^{18} \mathrm{O}$ values may have a crustal heritage, the younger magmas, particularly the A-type granites, became increasingly mantle-like in terms of their oxygen isotopic composition. This suggests that a series of important crust-forming events were taking place in east-central Asia in the late Phanerozoic.

The purposes of this paper are:

- to document the juvenile nature of the Phanerozoic granitoids from the ECAOB based on the existing and our unpublished $\mathrm{Nd}-\mathrm{Sr}$ isotopic data, and

- to discuss the general implications on the global Phanerozoic crustal growth.

We advocate that the granitic rocks of the ECAOB represent the most significant mass transfer from the mantle to the continental crust in the Phanerozoic.

\section{Brief account of lithological characters and emplacement periods of granites}

According to Kovalenko et al (1995), igneous activities in Mongolia and Transbaikalia continued throughout the entire Phanerozoic without any significant interruption. Most ages of magmatic rocks have been estimated by paleontological data and other stratigraphic means, only a small proportion has been determined by radiochronometric methods.

Since the early Paleozoic, numerous granitic rocks have been emplaced; they include

- the calc-alkaline series (tonalite-granodiorite-granite) of Caledonian ages in northern Mongolia and Transbaikalia (e.g., Angara-Vitim batholith, Litvinovsky et al 1992);

- the late Caledonian calc-alkaline series in western Mongolia and the alkaline series in Tuva, Sayan, eastern Mongolian Altai, and vast areas in northern Mongolia and Transbaikalia;

- the Hercynian (late Carboniferous to Permian) alkaline series in southern Mongolia to NE China and in northern Mongolia to Transbaikalia; Permian granitoids of the calc-alkaline series, represented by the vast Hangay batholith $\left(\approx 100,000 \mathrm{~km}^{2}\right)$ in Mongolia; and

- the early Mesozoic $(\approx 200 \mathrm{Ma})$ granites of the calcalkaline series and S-type granites in the MongolOkhotsk belt, plus the alkaline to peralkaline series in Transbaikalia.

Thus, the ECAOB is characterized by the occurrence of voluminous K-rich granitoids which include alkaline and peralkaline granites, syenogranites, syenites and minor granodiorites. Quartz and perthitic feldspar are predominant phases, accompanied by small amounts of plagioclase, mafic and other accessory minerals. Alkaline mafic minerals, such as arfvedsonite, riebeckite and aegirine-augite, are only found 
in late alkaline granites and syenites. Many plutons contain abundant miarolitic cavities and igneous layering formed by biotite-rich bands. Mafic enclaves are generally rare; but in Transbaikalia (Zanvilevich et al 1995; Wickham et al 1995, 1996) significant amounts of mafic rocks occur as enclaves and synplutonic dykes in granitoids of various ages.

The ages of granites roughly decrease from north to south within the ECAOB. In Transbaikalia and northern Mongolia, five main stages of K-rich magmatic activity have been distinguished (Zanvilevich et al 1995; Wickham et al 1995, 1996): (1) OrdovicianSilurian $(\approx 450 \mathrm{Ma}, \mathrm{U}-\mathrm{Pb}),(2)$ Devonian $(\approx 375 \mathrm{Ma})$, (3) Early Permian $(\approx 280 \mathrm{Ma})$, (4) Late Permian $(\approx 250 \mathrm{Ma})$, and $(5)$ Triassic $(\approx 220 \mathrm{Ma})$. In northern Xinjiang, granites of high-K to medium-K series appear to dominate; most of these were emplaced intruded in the period of 400-200 Ma (Hu et al 2000a, b). However, A-type granites, exposed mainly along the Ulungur River, were intruded at about $300 \mathrm{Ma}$ (Rb-Sr ages, Wang et al 1994; Han et al 1997). A-type granites in central inner Mongolia were emplaced slightly later at ca. $280 \mathrm{Ma}$ (whole-rock Rb-Sr, Hong et al 1995). In both northern Xinjiang and Inner Mongolia, in addition to A-type granites, granitoids of early Paleozoic to Mesozoic ages also occur. Further east to NE China the existing age data indicate three intrusive episodes for K-rich granitoids (Fang, 1992; Wu and Jahn, unpublished results): (1) late Permian (270-250 Ma), (2) late Triassic-early Jurassic (220-180 Ma), and (3) middle Jurassic (170-150 Ma). Thus, there is an apparent younging trend of granitic intrusions from the west to the east along the ECAOB.

In addition to the apparent regional age variation, two trends are also observed:

- a regular decrease in size for younger plutons, and

- an increase in the proportion of syenite and alkaline granite to granite (s.s.), as well as in the ratio of Kfeldspar to plagioclase, with the younging of plutons.

That is, the younger plutons tend to be more alkaline in nature. In Transbaikalia, peralkaline granites and syenites containing aegirine and arfvedsonite only occur in the younger Permian and Triassic suites (Kuzmin and Antipin 1993; Wickham et al 1995, 1996; Kononova et al 1996). However, we note that in the southern belt (Xinjiang-Inner Mongolia-NE China) such an increase of alkalinity of granitoids with the decrease of intrusive ages is not as clearly documented as in Transbaikalia (Hong et al 1996).

\section{Nd-Sr-O isotopic data for granitoids of the ECAOB}

Precise age data are vital to estimate the production rate of juvenile crust. However, within such volumi- nous granitoids in the ECAOB, only a few per cent of them have been reliably dated. Most of the intrusive ages reported in the literature are based on geological correlations or other non-radiochronometric means (Litvinovsky, personal comm.; see also Kovalenko et al 1995).

The age information and $\mathrm{Nd}-\mathrm{Sr}$ isotopic data used in this paper come from two sources:

- unpublished results obtained in Rennes (on granites of NE China and inner Mongolia), and

- results published in international journals, some of which were obtained in Rennes (Kovalenko et al1992; Zhao 1993; Hong et al 1995; Chen et al 1995; Zhou et al 1995; Arakawa and Shimura 1995; Han et al 1997).

We have included here the granitoids of the Hida Belt of Japan, which has been considered as part of the Asian continent prior to the opening of the Japan Sea (Hirooka et al 1983; Mizutani and Hattori 1983; Cluzel 1991).

All unpublished data are presented graphically and the analytical values will be reported elsewhere $(\mathrm{Wu}$ et al 2000). Figure 2 shows a plot of initial $\mathrm{Sr}$ isotopic ratios $\left(\mathrm{I}_{\mathrm{Sr}}\right)$ as a function of ${ }^{87} \mathrm{Rb} /{ }^{86} \mathrm{Sr}$ ratios for some granitoids from the southern belt of the ECAOB. High ${ }^{87} \mathrm{Rb} /{ }^{86} \mathrm{Sr}$ ratios (up to 100 ) are indicative of Atype and highly differentiated I-type granitoids. Note that the $I_{S r}$ values were individually calculated by subtracting the radiogenic components from the measured ${ }^{87} \mathrm{Sr} /{ }^{86} \mathrm{Sr}$ ratios; they may bear large uncertainties for high $\mathrm{Rb} / \mathrm{Sr}$ rocks, and not uncommonly yield unreasonably low ratios of less than 0.700 (figure 2). The $\mathrm{Rb} / \mathrm{Sr}$ induced errors $(\xi)$ for calculated initial ${ }^{87} \mathrm{Sr} /{ }^{86} \mathrm{Sr}$ ratios are related to three factors: $\mathrm{Rb} /$ $\mathrm{Sr}$ ratio, assigned uncertainty for the $\mathrm{Rb} / \mathrm{Sr}$ ratio, and isochron age, all related by the equation:

$$
\xi={ }^{87} \mathrm{Rb} /{ }^{86} \mathrm{Sr} \times \% \text { error } \times\left(e^{\lambda t}-1\right) .
$$

Take, for example, three cogenetic $300 \mathrm{Ma}$ granites with ${ }^{87} \mathrm{Rb} /{ }^{86} \mathrm{Sr}$ ratios of 1,10 , and 100 . If a $2 \%$ error is assigned for their ${ }^{87} \mathrm{Rb} /{ }^{86} \mathrm{Sr}$ ratios, then they would have uncertainties for the calculated initial ${ }^{87} \mathrm{Sr} /{ }^{86} \mathrm{Sr}$ ratios of $\pm 0.000085, \pm 0.00085$, and \pm 0.0085 , respectively. Thus, assuming the initial ${ }^{87} \mathrm{Sr} /{ }^{86} \mathrm{Sr}$ ratio for them to be 0.705 , a calculated $\mathrm{I}_{\mathrm{Sr}}$ for the third granite as low as 0.6965 is possible, though completely meaningless. We note that a single unreasonably low $\mathrm{I}_{\mathrm{Sr}}$ of 0.698 was reported for a granite of relatively low $\mathrm{Rb} /$ Sr ratio $\left({ }^{87} \mathrm{Rb} /{ }^{86} \mathrm{Sr} \approx 1.2\right)$ from western Mongolia (Kovalenko et al 1992). This is likely to be due to postmagmatic $\mathrm{Rb} / \mathrm{Sr}$ open system behavior or some analytical problem. Nevertheless, most $\mathrm{I}_{\mathrm{Sr}}$ values for low $\mathrm{Rb} / \mathrm{Sr}$ rocks seem to show a restricted range of $\mathrm{I}_{\mathrm{Sr}}$ values from 0.702 to 0.707 (figure 2), which is rather low for most granitic rocks formed in Phanerozoic orogenic belts. The data suggest that contribution of 


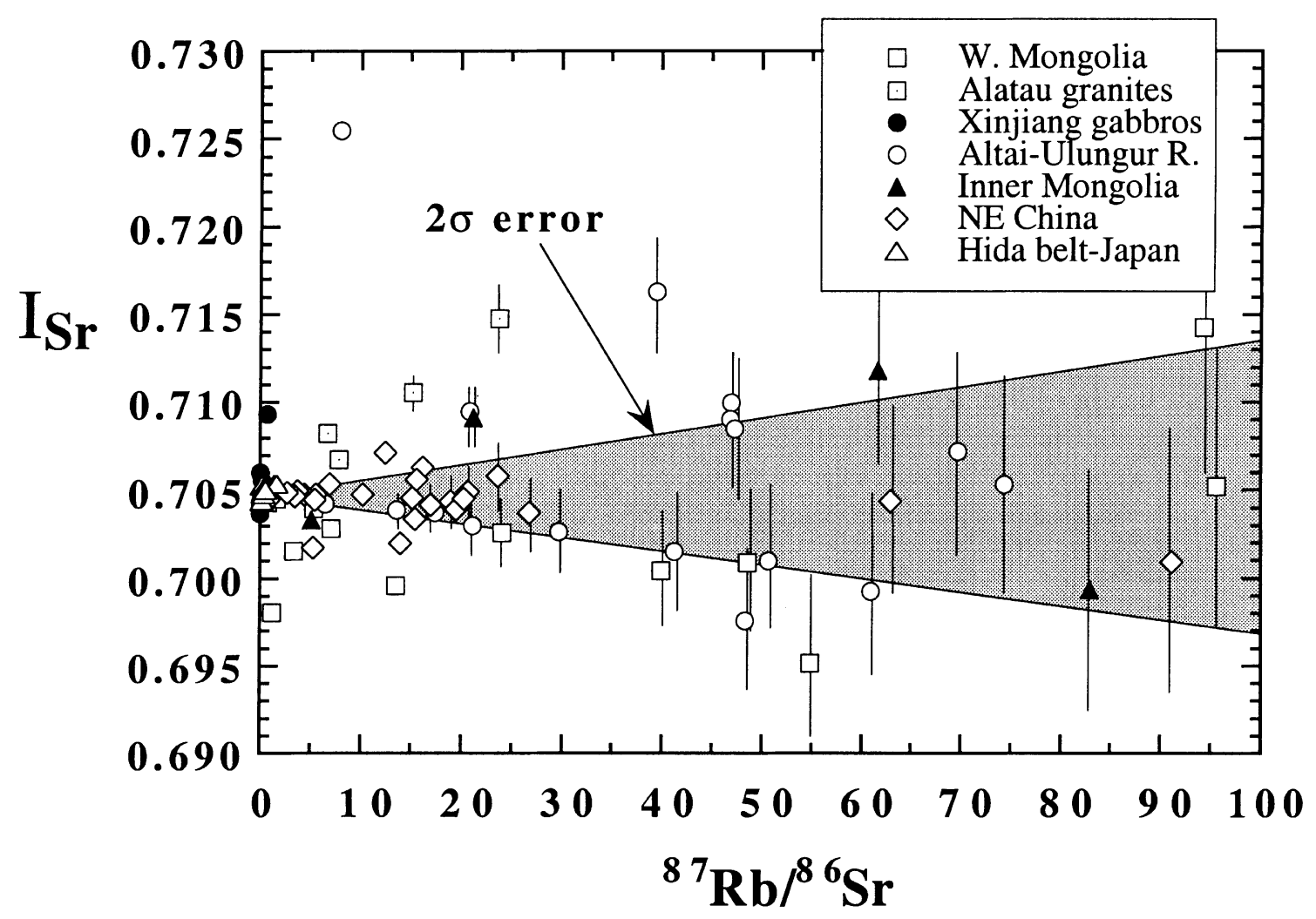

Figure 2. Initial ${ }^{87} \mathrm{Sr} /{ }^{86} \mathrm{Sr}\left(=\mathrm{I}_{\mathrm{Sr}}\right)$ vs ${ }^{87} \mathrm{Rb} /{ }^{86} \mathrm{Sr}$ plot for Phanerozoic granitoids from the ECAOB. Data of Xinjiang gabbros (Chen et al 1995) are also shown for comparison. The more reliable $\mathrm{I}_{\mathrm{Sr}}$ values for rocks with $\mathrm{Rb} / \mathrm{Sr}$ ratios less than 20 are found between 0.702 and 0.707 , a range considered as relatively low for Phanerozoic granitic rocks. $\mathrm{I}_{\mathrm{Sr}}$ values calculated from rocks with high to very high $\mathrm{Rb} / \mathrm{Sr}$ ratios are too imprecise to have any useful petrogenetic meanings. Grey area indicates the propagation of error size induced by $2 \% \mathrm{Rb} / \mathrm{Sr}$ uncertainty in $\mathrm{I}_{\mathrm{Sr}}$ values.

ancient crustal material in the petrogenesis of these granitic rocks was limited.

Relative to $\mathrm{Sr}, \mathrm{Nd}$ isotopic data can provide a much clearer constraint to the origin of granitic rocks. Many Altaid granites are characterized by positive $\varepsilon_{\mathrm{Nd}}(\mathrm{T})$ values (figure 3 ). The ranges for individual terrains are: +6.7 to +5.1 for 21 A-type granites of Xinjiang (Zhao 1993; Han et al 1997), +5.4 to +3.0 for 4 Atype granites of Inner Mongolia (Jahn, unpublished), and +2.8 to +1.2 for 25 highly differentiated I-type granites from NE China (Wu et al 2000). In addition, a variety of granitic rocks from northern Xinjiang indicate a range of $\varepsilon_{\mathrm{Nd}}(\mathrm{T})$ values from as high as +7 for alkali granites from the Ulungur River area to as low as -5 for biotite granites from other localities (Zhao 1993). Kovalenko et al (1992) obtained a range of $\varepsilon_{\mathrm{Nd}}(\mathrm{T})$ values from +7.7 to +3.0 for 17 granitic rocks (age $\approx 378 \mathrm{Ma}$ ) from the Altai Mountains of western Mongolia. Additional data for granites of the Alatau Mountains and for gabbros of west Tianshan in western Xinjiang are shown for comparison in figure 3 . Note that many of the granitic rocks have the same $\varepsilon_{\mathrm{Nd}}(\mathrm{T})$ values as the mantle-derived gabbroic rocks. These data thus provide strong evidence for depleted material as the major source of magmatism in the southern belt of the ECAOB. The same conclusion was also reached from $\mathrm{Pb}$ isotopic studies on K-feldspars of granitoids from the western Junggar region in Xinjiang (Kwon et al 1989; Jin and Zhang 1993).

These isotopic data are in strong contrast to those for most Phanerozoic granites occurring in the classical collisional orogens. The latter were mainly produced by remelting of older continental crust and are characterized by negative $\varepsilon_{\mathrm{Nd}}(\mathrm{T})$ and high $\mathrm{I}_{\mathrm{Sr}}$ values, as exemplified by the Hercynian granites of south Brittany and the Massif Central in France, and the Manaslu leucogranites of the Himalayas (figure 4). So far, we are not aware of any coupled Nd-Sr isotopic data published for granites of Transbaikalia. However, the Triassic Kharitonovo pluton of Transbaikalia (alkaline and peralkaline rocks, $\mathrm{T} \approx 240-220 \mathrm{Ma}$ ) is characterized by low initial ${ }^{87} \mathrm{Sr} /{ }^{86} \mathrm{Sr}$ ratios of about 0.704 (Zanvilevich et al 1995). This pluton has a range of "primary" magmatic whole-rock $\delta^{18} \mathrm{O}$ values of +6.5 to $+4.5 \%$, deduced from alteration-resistant titanite $\delta^{18} \mathrm{O}$ data (ca. +3 to $+0.5 \%$ ) , which is consistent with derivation from upper mantle rocks (Wickham et al 1995, 1996).

Sm-Nd fractionation during magma genesis may change model ages to some extent, depending on the partition coefficient of $\mathrm{Sm} / \mathrm{Nd}$ of the fractionated 


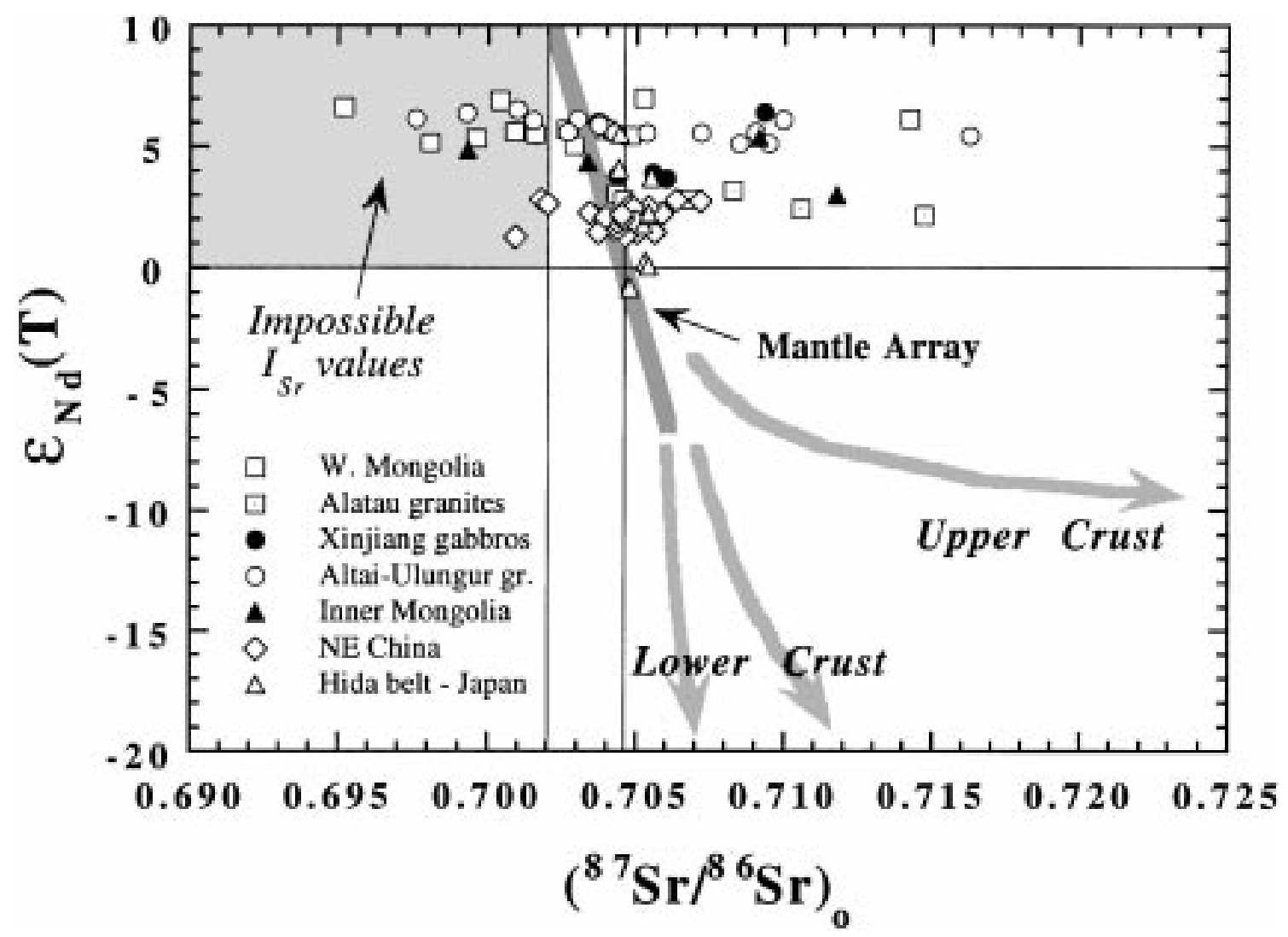

Figure 3. Plot of $\varepsilon_{\mathrm{Nd}}(\mathrm{T})$ vs initial ${ }^{87} \mathrm{Sr} /{ }^{86} \mathrm{Sr}$ isotopic ratios for Phanerozoic granitoids from the ECAOB. Data for Tianshan gabbros of Xinjiang are also shown for comparison. The calculated $\left({ }^{87} \mathrm{Sr} /{ }^{86} \mathrm{Sr}\right)_{\mathrm{o}}$ or $\mathrm{I}_{\mathrm{Sr}}$ values have a wide range, which is due partly to the large uncertainty inherent in rocks of high $\mathrm{Rb} / \mathrm{Sr}$ ratios and partly to open system in low Sr alkaline granites. However, the restricted and positive $\varepsilon_{\mathrm{Nd}}(\mathrm{T})$ values are indicative of the juvenile characteristics and formation of new continental crust.

phases. Rocks with high $\mathrm{f}_{\mathrm{Sm} / \mathrm{Nd}}$ ratios (e.g., -0.2 to 0 , or positive values) are often observed in A-type granites produced through fractional crystallisation; they often produce aberrant and meaningless $\mathrm{T}_{\mathrm{DM}}$ ages. Similarly, some of the very low $\mathrm{Sm} / \mathrm{Nd}$ ratios or highly negative $f_{\mathrm{Sm} / \mathrm{Nd}}$ values $(-0.6$ to -0.7$)$ as shown in figure 5 could also reflect a fractionation effect. However, the young and small range of $\mathrm{T}_{\mathrm{DM}}$ ages, covering a large variation of $\mathrm{f}_{\mathrm{Sm} / \mathrm{Nd}}$ values (figure 5 ), cannot be only due to REE fractionation. The overall scenario is convincing evidence for a significant mantle contribution in the genesis of these granites.

Abundant Nd isotopic data have been published by Kovalenko et al $(1992,1996)$ for Phanerozoic granitic rocks from the central to northern belts of the ECAOB (Mongolia and Transbaikalia). Using the Nd model age $\left(\mathrm{T}_{\mathrm{DM}}\right)$ approach, Kovalenko et al (1996) delineated three isotope provinces (Caledonian, Hercynian, and pre-Riphean) which coincide with three tectonic zones of corresponding ages. In each province the model ages are limited in a narrow range, regardless of the emplacement age of the granites. We re-summarize their $\mathrm{Nd}$ isotopic data in figures 6-8. Without exception, Phanerozoic granites emplaced into Caledonian and Hercynian tectonic zones have positive $\varepsilon_{\mathrm{Nd}}(\mathrm{T})$ values, suggesting their juvenile characteristics; whereas those intruded into the pre-Riphean basement show variable $\varepsilon_{\mathrm{Nd}}(\mathrm{T})$ from positive to negative values, hence indicating variable proportions of old Precambrian crust mixed with the mantle peridotite in their source (figure 6). Note that some late Neoproterozoic to early Paleozoic granites $(600-500 \mathrm{Ma})$ have $\varepsilon_{\mathrm{Nd}}(\mathrm{T})$ values as high as +10 , indicating their derivation from an almost pure depleted mantle component.

Figure 7 illustrates that the majority of the rocks emplaced in the Caledonian and Hercynian belts have Sm-Nd model ages $\left(\mathrm{T}_{\mathrm{DM}}\right)$ younger than $1000 \mathrm{Ma}$, whereas those intruded in the Precambrian terranes have an older range from ca. 800 to $2500 \mathrm{Ma}$. If the rocks with high $f_{\mathrm{Sm} / \mathrm{Nd}}$ values $(\geq-0.2$, shown in the grey region of figure 8) are excluded, then all granitoids from Mongolia and Transbaikalia would have $\mathrm{T}_{\mathrm{DM}}$ limited to $1500 \mathrm{Ma}$ (figure 8). Nevertheless, granites intruded in the Pre-Riphean basement generally have lower $\varepsilon_{\mathrm{Nd}}(\mathrm{T})$ values and higher $\mathrm{T}_{\mathrm{DM}}$ than those intruded in the Caledonian and Hercynian belts. This is consistent with the nature of the crustal contaminant (older), but not necessarily a greater proportion of crust/mantle mixing. 


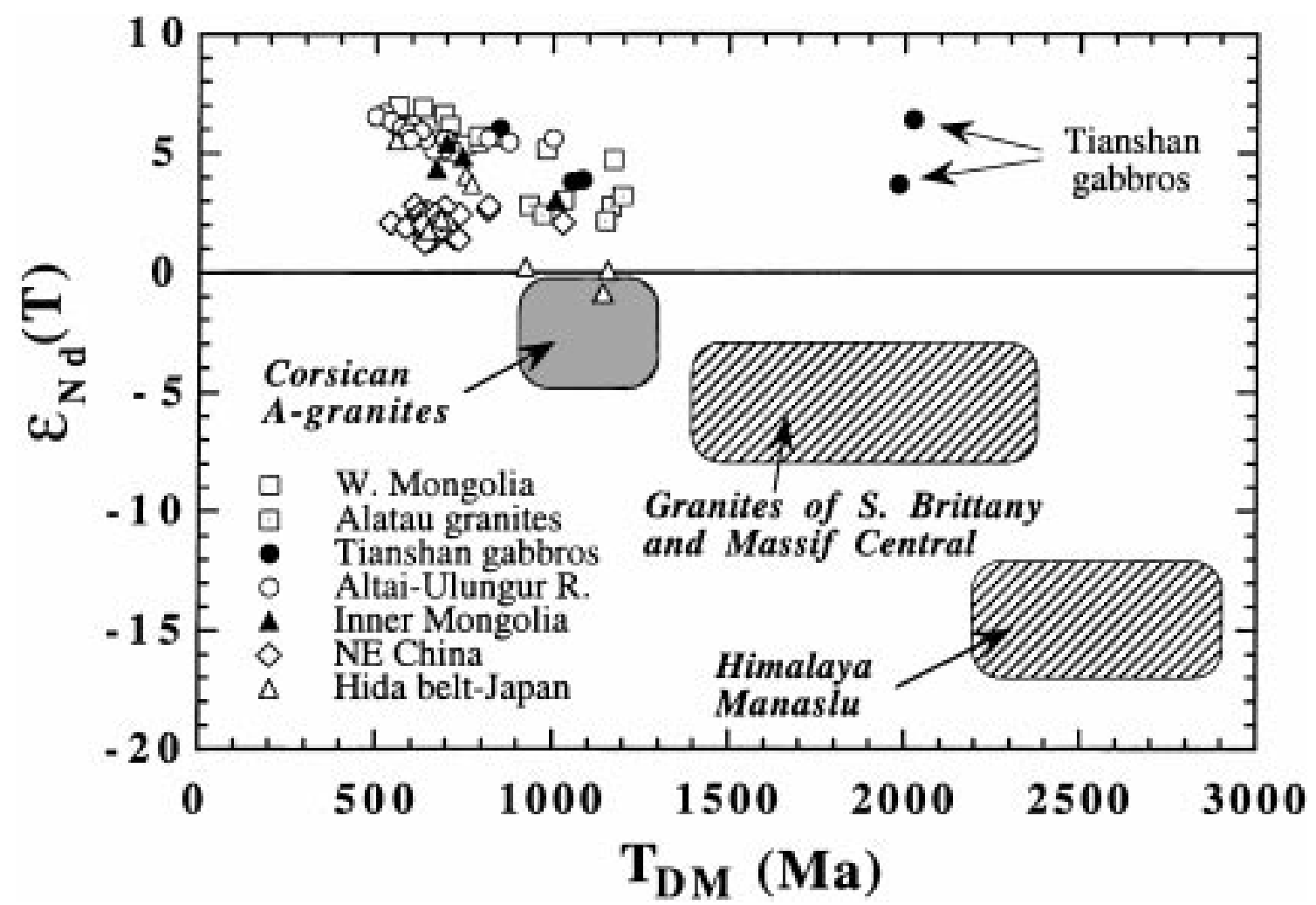

Figure 4. $\quad \varepsilon_{\mathrm{Nd}}(\mathrm{T})$ vs $\mathrm{T}_{\mathrm{DM}}$ plot for Phanerozoic granitoids from the ECAOB. Data for Tianshan gabbros of Xinjiang are shown for comparison. The model ages are young, ranging from 500 to $1200 \mathrm{Ma}$, and are in strong contrast with those of the majority of Phanerozoic granitic rocks in the world. The young $\mathrm{T}_{\mathrm{DM}}$ of the Altaid granites suggest their derivation from depleted mantledominated source rocks. Data sources: Corsican A-type granites (Poitrasson et al 1995); granites of S. Brittany (BernardGriffiths etal 1985); granites of Massif Central (Downes et al 1997); leucogranites of Himalaya-Manaslu (Vidal et al 1984); Tianshan gabbros (Chen et al 1995).

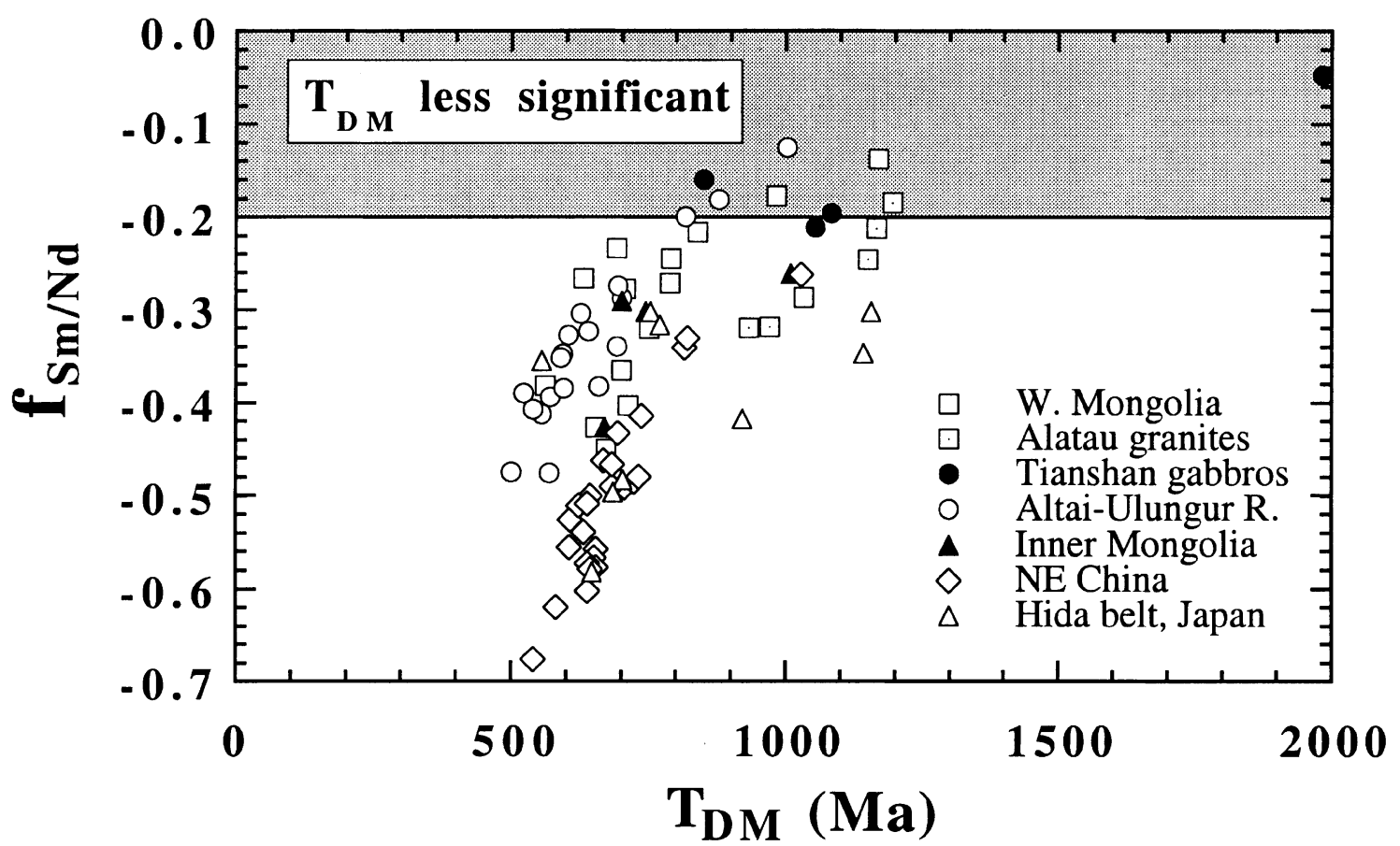

Figure 5. $\mathrm{f}_{\mathrm{Sm} / \mathrm{Nd}}$ vs $\mathrm{T}_{\mathrm{DM}}$ plot for Phanerozoic granitoids from the ECAOB. Data for Tianshan gabbros are shown for comparison. $\mathrm{T}_{\mathrm{DM}}$ for rocks with $\mathrm{f}_{\mathrm{Sm} / \mathrm{Nd}}$ values higher than -0.2 (or ${ }^{147} \mathrm{Sm} /{ }^{144} \mathrm{Nd}$ ratio of 0.157 ) may produce large uncertainty in model age calculation, hence they are less significant and excluded from discussion. Despite the large range of $\mathrm{f}_{\mathrm{Sm} / \mathrm{Nd}}$ values, the calculated model ages are "young" in comparison with most Phanerozoic granitic rocks (ca. 1.5 to 2.0 Ga). 


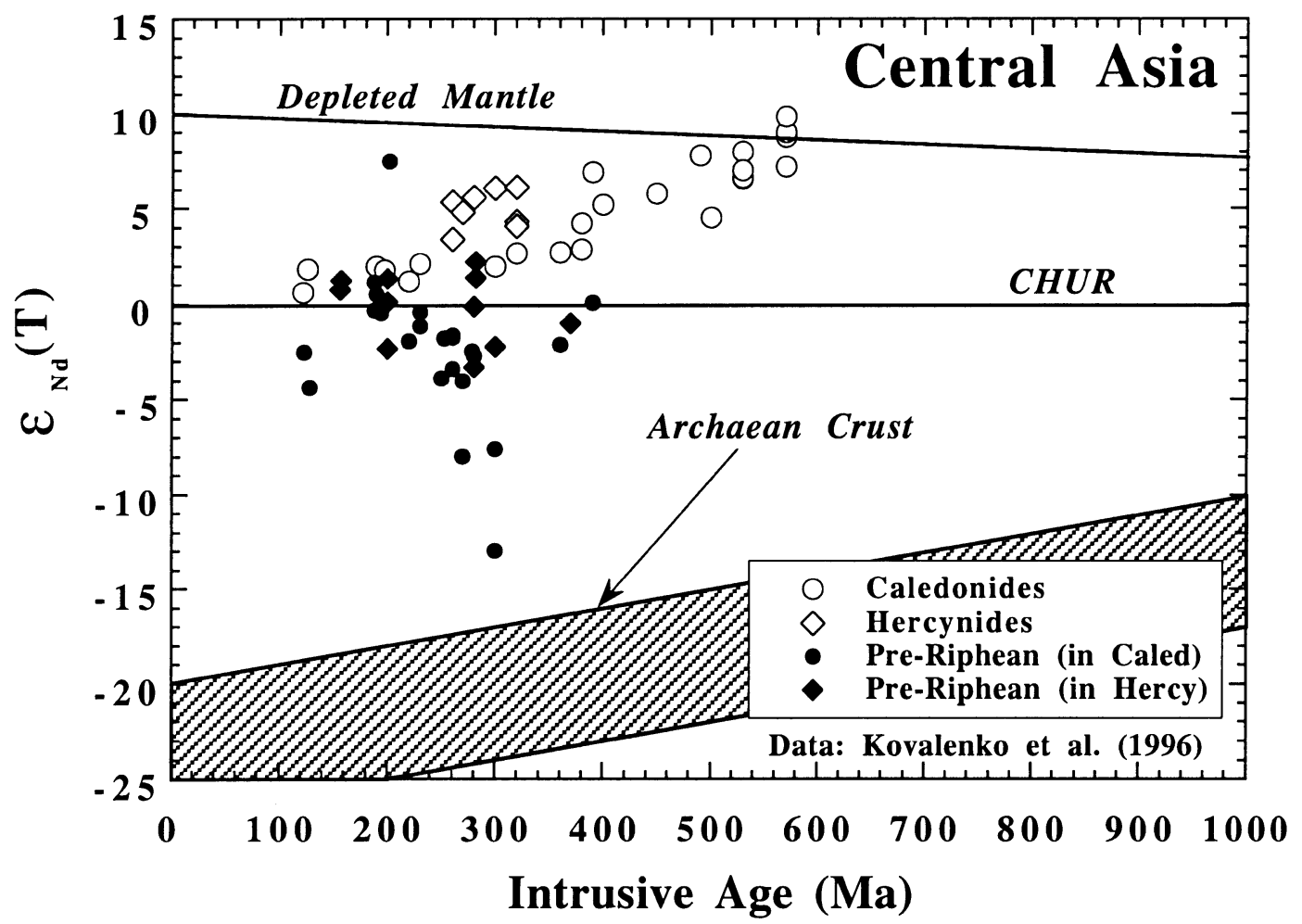

Figure 6. $\quad \varepsilon_{\mathrm{Nd}}(\mathrm{T})$ vs intrusive age plot for Phanerozoic granitoids from Mongolia and Transbaikalia (data from Kovalenko et al 1996). Granites intruded in Caledonian and Hercynian belts (open symbols) are characterized by positive $\varepsilon_{\mathrm{Nd}}(\mathrm{T})$ values, whereas those intruded in pre-Riphean basement "enclaves" within Caledonian and Hercynian belts (black symbols) have both positive and negative $\varepsilon_{\mathrm{Nd}}(\mathrm{T})$ values.

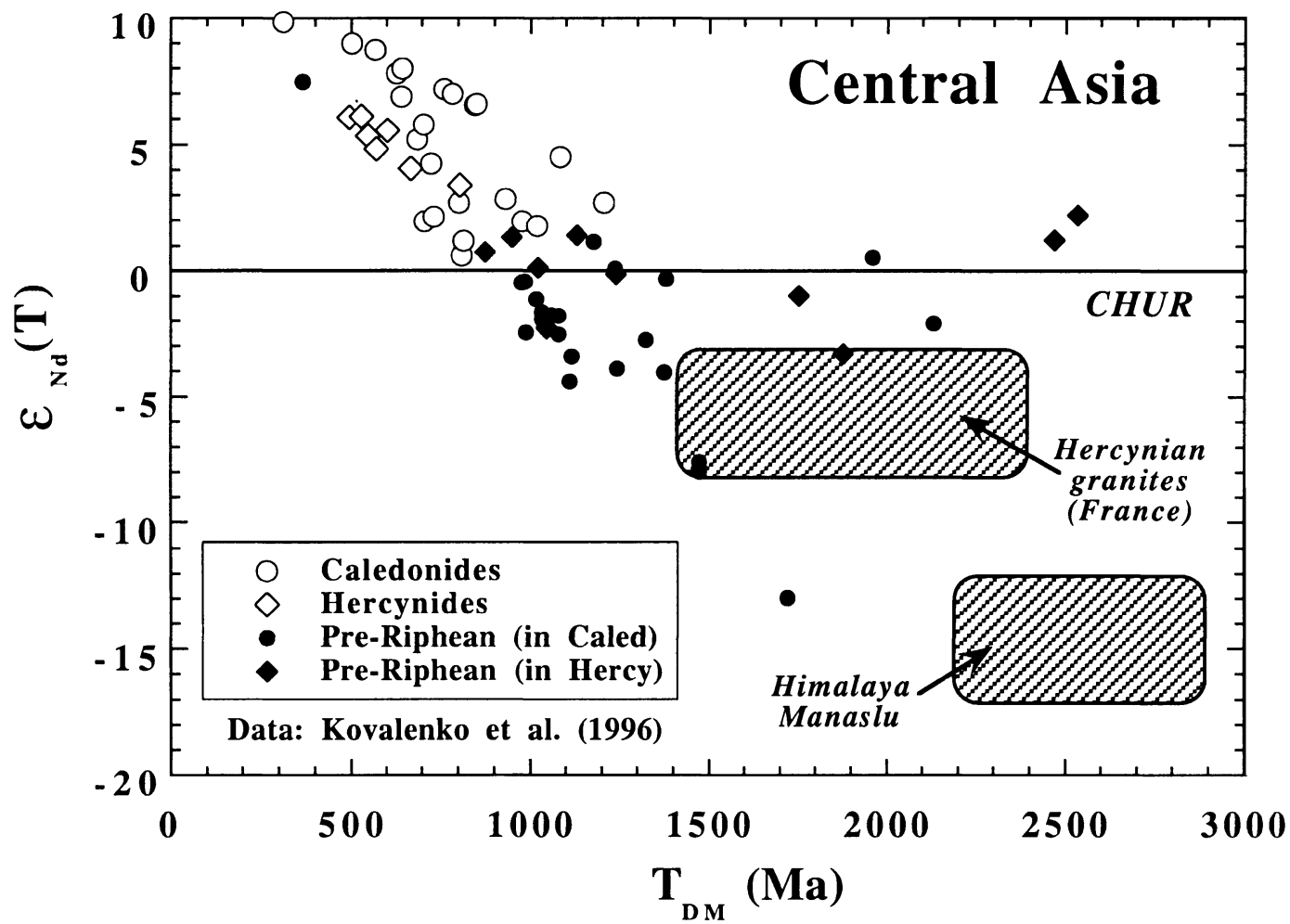

Figure 7. $\varepsilon_{\mathrm{Nd}}(\mathrm{T})$ vs $\mathrm{T}_{\mathrm{DM}}$ plot for Phanerozoic granitoids from Mongolia and Transbaikalia (data from Kovalenko et al 1996). Model ages $\left(\mathrm{T}_{\mathrm{DM}}\right)$ are young (300 to $1200 \mathrm{Ma}$ ) for those intruded in Caledonian and Hercynian belts, which are similar to Phanerozoic granitic rocks from the southern belt of the ECAOB. $\mathrm{T}_{\mathrm{DM}}$ are generally older (800-2500 Ma) for those intruded in pre-Riphean basement, suggesting more involvement of Precambrian crustal material in their petrogeneses. 


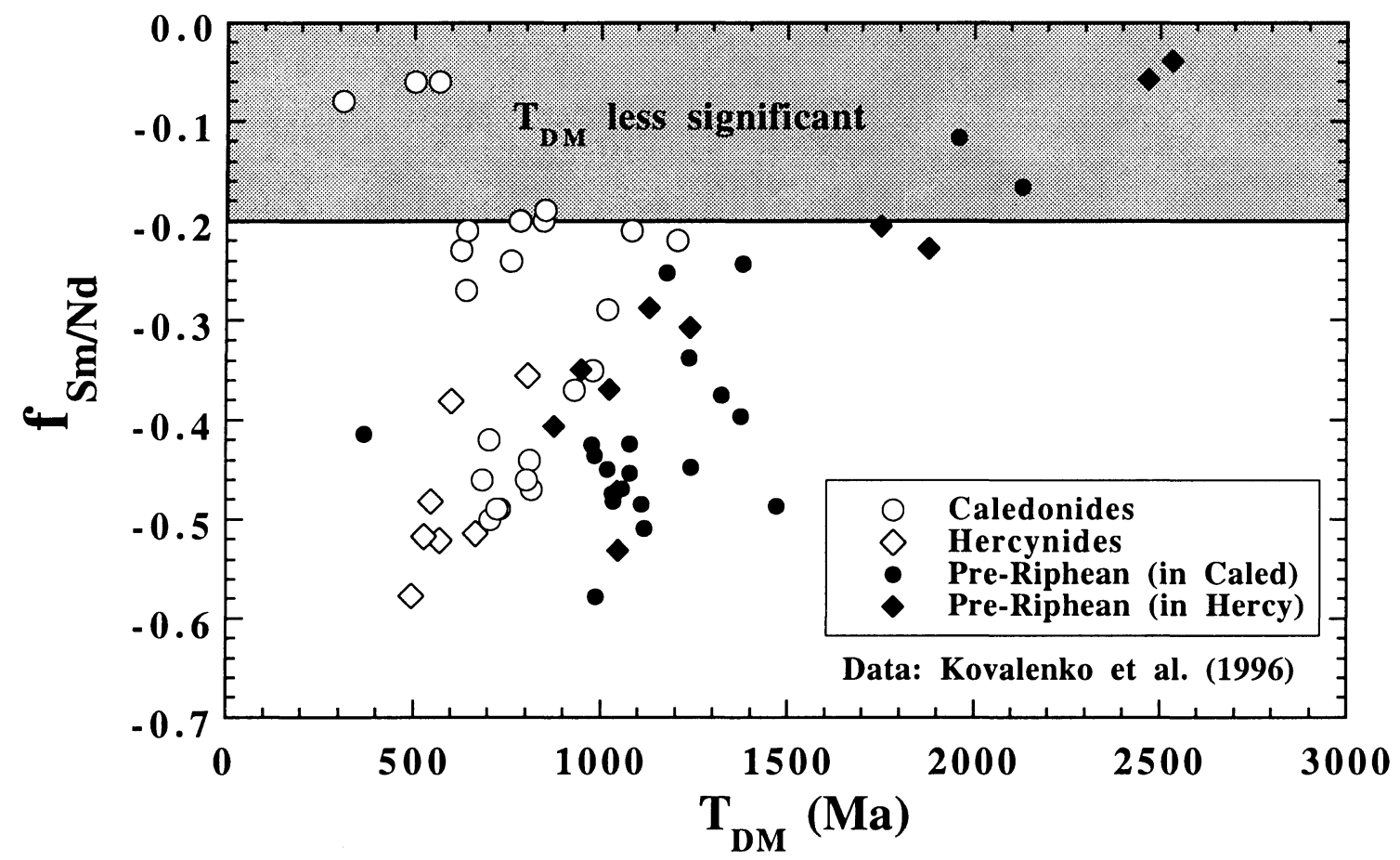

Figure 8. $\mathrm{f}_{\mathrm{Sm} / \mathrm{Nd}}$ vs $\mathrm{T}_{\mathrm{DM}}$ plot for Phanerozoic granitoids from Mongolia and Transbaikalia (data from Kovalenko et al 1996). The data in the grey zone are excluded from discussion. The calculated model ages are still "young" in comparison with most Phanerozoic granitic rocks (ca. 1.5 to $2.0 \mathrm{Ga}$ ).

\section{Discussion}

\section{A Genesis of the Phanerozoic crust}

Until now, the best documented examples of Phanerozoic juvenile granitic rocks are those from the Mesozoic Sierra Nevada and Peninsular Range batholiths in the western U.S. (DePaolo 1981), the Canadian Cordillera (Samson et al 1989; Samson and Patchett 1991), and the Appalachians (Whalen et al 1996; Samson 1998). While a significant mantle contribution to the generation of the Altaid granitoids is indicated by the $\mathrm{Nd}$ isotopic evidence, the precise mechanisms for the growth and evolution of the Phanerozoic continental crust remain debatable. Several pertinent questions include:

(1) Could subduction processes (Sengör et al 1993) alone be responsible for formation of the juvenile crust?

(2) Could the granites in this region have been formed by partial melting of a "young" mafic lower crust which was underplated during post-thickening extensional collapse, as envisioned for the Hercynides in the Massif Central (Costa and Rey 1995)?

(3) Was intraplate magmatism a significant process of continental growth, particularly during the Phanerozoic?

(4) Did the underplated mantle melts (basaltic liquids) interfinger with pre-existing granulites of various compositions, much like the model given by Wickham et al (1996), which together were then melted to produce granite, with the residue sinking back into the mantle by processes like delamination?

(5) Is the Phanerozoic a major period of continental growth? If so, would that significantly alter the commonly accepted scenario of the growth of continental crust?

Because crustal growth curves were also determined in part from the Sm-Nd model age approach, erroneous conclusions may be reached if the material did not come from the depleted mantle, or important Sm/ $\mathrm{Nd}$ fractionation occurred during melting and magma differentiation processes (Arndt and Goldstein 1987; Jahn et al 1990). Besides, what was the relative role of lithospheric and asthenospheric mantle as the dominant "mantle component" (Whalen et al 1996)?

In any case, the striking feature for the granites in the ECAOB is their relatively high $\varepsilon_{\mathrm{Nd}}(\mathrm{T})$ values and low $\mathrm{T}_{\mathrm{DM}}$ model ages (and probably, low $\mathrm{I}_{\mathrm{Sr}}$ ratios). Windley $(1993,1995)$ distinguishes two types of orogens:

- collisional orogens, formed by the collision of two or more large continental blocks (e.g., Himalayas, Alps, Grenville, etc.), and

- accretionary orogens, formed by the growth and amalgamation of island arcs, intervening accretionary prisms, etc. (e.g., Altaids, North American Cordillera, Andes, Birimian, Nubian-Arabian, etc.). A depleted isotopic character is unusual for granitic rocks of collisional orogens worldwide, except a few 
as exemplified by the Newfoundland Appalachians (Whalen et al 1996), but are more commonly observed for those in accretionary orogens. High $\varepsilon_{\mathrm{Nd}}(\mathrm{T})$ values could reflect a direct contribution of mantle in subduction zones (DePaolo 1981; Farmer and DePaolo 1983). However, abundant A-type granites are post-orogenic and appear to have no direct connection with subduction processes. Thus, it appears that subduction processes alone could not have been responsible for the formation of all the juvenile crust (Question 1).

\section{B Implication for the origin of alkaline and peralkaline granitoids}

Although many plutons and batholiths of the ECAOB belong to the calc-alkaline series and have differentiated I-type characteristics, the emplacement of voluminous granites of the alkaline and peralkaline series $(\mathrm{A} / \mathrm{NK} \leq 1$ and $\mathrm{A} / \mathrm{CNK} \leq 1$, with $\mathrm{A}, \mathrm{C}, \mathrm{N}, \mathrm{K}=$ molecular proportion of $\mathrm{Al}_{2} \mathrm{O}_{3}, \mathrm{CaO}, \mathrm{Na}_{2} \mathrm{O}$ and $\mathrm{K}_{2} \mathrm{O}$, respectively) is remarkable. Of these rocks, many are post-orogenic A-type granites $(\mathrm{A} / \mathrm{CNK} \leq 1)$. The origin of A-type granites is still much debated, and it appears that no single petrogenetic model is applicable for all cases (Whalen et al 1987; Eby 1992). Mechanisms involving melting of crustal sources are favored from trace element geochemistry (Collins et al 1982; Creaser et al 1991; Anderson and Morrison 1992; Turner et al 1992; Cocherie et al 1994; Poitrasson et al 1995; Landenberger and Collins 1996), whereas mantle sources are often advocated from isotopic constraints (Javoy and Weiss 1987; Foland and Allen 1991; Turner et al 1992; Whalen et al 1996; Han et al 1997). However, this is not universally true, as many A-type granites are known to have a crustal isotopic signature

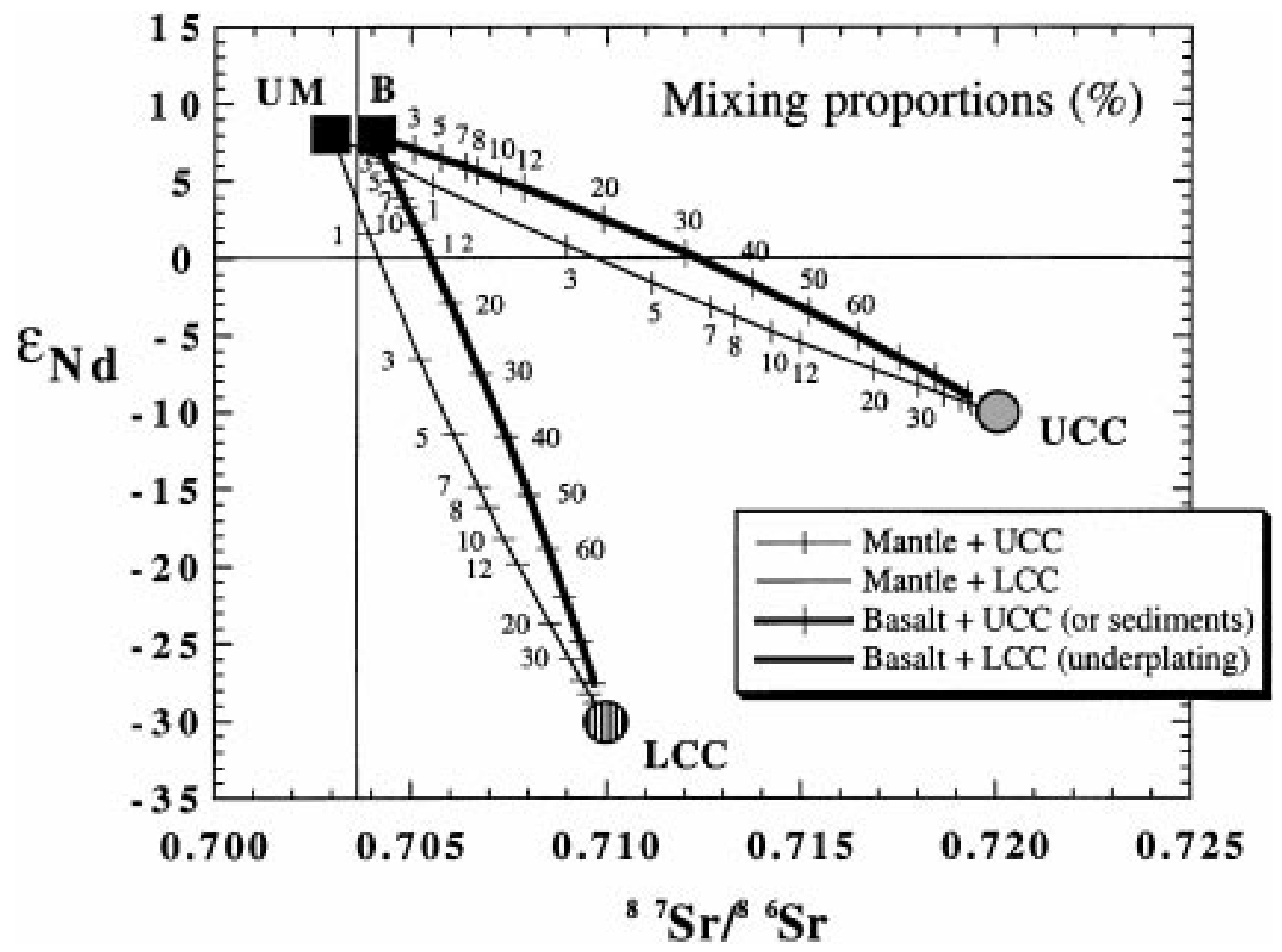

Figure 9. $\quad \varepsilon_{\mathrm{Nd}} \mathrm{vs}^{87} \mathrm{Sr} /{ }^{86} \mathrm{Sr}$ isotopic ratio plot showing mixing proportions between two end-members: (1) depleted mantle or juvenile components ( $\mathrm{UM}=$ upper mantle peridotite; or B = basalt) and (2) crustal components (LCC = lower continental crust; or $\mathrm{UCC}=$ upper continental crust). The parameters used are:

\begin{tabular}{lcccc}
\hline & UM & Basalt & UCC & LCC \\
\hline${ }^{87} \mathrm{Sr} /{ }^{86} \mathrm{Sr}$ & 0.703 & 0.704 & 0.720 & 0.710 \\
{$[\mathrm{Sr}] \mathrm{ppm}$} & 20 & 150 & 350 & 300 \\
$\varepsilon_{\mathrm{Nd}}$ & +8 & +8 & -10 & -30 \\
{$[\mathrm{Sm}] \mathrm{ppm}$} & 0.42 & 3.5 & 5.2 & 4.8 \\
{$[\mathrm{Nd}] \mathrm{ppm}$} & 1.2 & 15 & 26 & 24 \\
$\mathrm{Sr} / \mathrm{Nd}$ & 16.7 & 10 & 13.5 & 2.5 \\
\hline
\end{tabular}

Sr and Nd concentrations of the UCC from Taylor and McLennan (1985), and those of the LCC from Rudnick and Fountain (1995). 
(Charoy and Raimbault 1994; Darbyshire and Sewell 1997). In most cases, rocks of mantle derivation have also been contaminated by crustal material to some extent. Models involving mixing of mantle-derived magmas and crustal components (assimilated crustal rocks or crust-derived magmas), followed by fractional crystallisation are becoming increasingly popular.

A detailed discussion of petrogenetic models for the Altaid granites is beyond the scope of this paper, but it can be found in several related works (Hong et al 1995; Han et al 1997; Wu et al 2000). The available trace element and Nd-Sr isotopic compositions of the A-type (Xinjiang and Inner Mongolia) and differentiated I-type granites (NE China) indicate the mixing model as the most probable process and the dominance of mantle component over crustal material (e.g., Kovalenko et al 1996). A simple mixing calculation using different end-members is shown in figure 9 . Two depleted juvenile components are used-mantle peridotite (UM) and basaltic rock (B). Because many $\mathrm{I}_{\mathrm{Sr}}$ values have large uncertainties, we estimate the mixing proportions by using $\mathrm{Nd}$ isotopic compositions only. In all cases, granites with positive $\varepsilon_{\mathrm{Nd}}(\mathrm{T})$ values would represent at least $70 \%$ juvenile component if upper continental crust (UCC) is the crustal endmember, and $\geq 85 \%$ if lower continental crust (LCC) is considered. For the granites from the ECAOB, the majority of the southern belt (figures 4,5 ) and those emplaced in the Caledonian and Hercynian zones in Mongolia and Transbaikalia (figures 6,7) would be 100 to $80 \%$ juvenile. This implies extensive mantle differentiation and rapid crustal growth during the Phanerozoic. However, those emplaced in the Pre-Riphean zones have variable mixing proportions, from roughly 15 to $50 \%$ juvenile component (using Curve B-LCC, figure 9). It appears that the production of a huge amount of alkaline to peralkaline granites was initiated by extensive basalt underplating and accompanied by large-scale crustal extension (Questions 2 and 4, section 4.A). Consequently, intraplate magmatism was probably a significant process of continental growth in the Phanerozoic (Questions 3 and 5).

\section{C Tectonic model of Altaid collage by Sengör et al} (1993)

Sengör et al (1993) published an important and stimulating paper on the evolution of the Altaid tectonic collage. It provides an excellent forum for further research. According to this and a subsequent article (Sengör and Natal'in 1996), the Altaids (including the ECAOB and the region westwards to the Urals) provide a spectacular example of continental enlargement in the Phanerozoic, and their tectonic evolution involves accretion of arc complexes. The above authors have estimated that about 5.3 million $\mathrm{km}^{2}$ of material accreted to Asia, half of which may be of juvenile origin. Here we point out a few problems with this general model:

(1) The idea of using "magmatic front" as a new kind of structural marker in the reconstruction of the tectonic evolution is very creative, but the validity of this approach hinges on reliable age data for all individual granitic plutons. At present, this is far from the reality, and the number of plutons with precise age determination is very small in comparison with the total number of granitic plutons in the ECAOB. We cite here an example of granitoids in NE China. These rocks were assigned Hercynian or late Paleozoic ages (see published geologic maps), but, more recently, they have been found to be Indosinian $(\approx 200 \mathrm{Ma})$ based on some preliminary $\mathrm{Rb}-\mathrm{Sr}$ and $\mathrm{K}$ Ar dating results. However, our whole-rock and mineral Rb-Sr and Ar-Ar analyses for three of these "Indosinian" plutons show that they were intruded separately during a time interval of 165 to $140 \mathrm{Ma}$ (Wu, Jahn and Lo, unpublished). The above example of incorrect age assignment by geological correlations is not an isolated case in the ECAOB. Until more precise age data are obtained, the tectonic model based on the magmatic front concept must inevitably involve large uncertainties.

(2) The model of Sengör et al (1993) suggests that the orogenic belts forming the Altaid collage have evolved dominantly along a single subuction zone, in front of a migratory island arc, called the Kipchak arc. In other words, the entire process of arc accretion is achieved by back-stepping of a single subuction zone. Such a process appears to be oversimplistic, particularly with regard to the presence of ancient crustal blocks within the vast ECAOB (see point 3 below). It is questionable, therefore, whether the separately identifiable and seemingly independent arc complexes must be regarded as disrupted and displaced fragments of a single Kipchak arc.

(3) The model stresses the paucity of ancient gneiss terrains that represent ancient continental fragments. Although our Nd isotopic data indicate a very significant mantle input for the generation of the Altaid granitoids, the data of Kovalenko et al (1996) for Mongolia and Transbaikalia and those for Xinjianginner Mongolia-NE China (see also Zhao 1993; Hu et al 2000a,b) also suggest the presence of older crustal rocks in the ECAOB. Even the young model ages $\left(\mathrm{T}_{\mathrm{DM}}\right)$ of $500-1000 \mathrm{Ma}$ are still considerably older than the intrusive ages, suggesting the presence of older crust in the granite petrogenesis. The significant negative $\mathrm{Nb}$ anomalies in geochemical spidergrams observed in the A-type granites of Xinjiang (Han et al 1997) and inner Mongolia (Hong et al 1995) and in the I-type granites of NE China (Wu et al 2000) are in perfect agreement with the idea that old crustal rocks were involved in the granite petrogenesis. Consequently, the presence of older crustal blocks, 
in addition to island arc complexes, is not insignificant in the Altaid collage.

(4) The importance of A-type granites appears to be downplayed in the model of Sengör et al (1993), which indicates that high-K granites were only generated widely in the Permian through anatectic magmatism. The high-K granites (A-type) of the Ulungur River, northern Xinjiang, were emplaced in the Carboniferous $(\approx 300 \mathrm{Ma})$ and were generated by melting of sources dominated by mantle components (Han et al 1997; figures 3 and 4). The "anatectic" origin of high-K granites (Sengör et al 1993) is in contradiction with the isotopic data. By contrast, Coleman (1989) suggested that all A-type granites are generated by underplating of basaltic magmas in the lower crust, followed by partial melting of a mixed lower crustal assemblage. It is speculated that the voluminous post-orogenic A-type granites emplaced (mainly?) during the late Paleozoic could be related to a mantle plume, which supplied the necessary mantle material for the ultimate granite geneses and the necessary thermal energy for lithospheric extension.

\section{D Comparison between the granitoids of the Altaids and Cathaysia}

Cathaysia in the Yangtze Craton (figure 1) is a major Phanerozoic orogenic belt in SE China. Like the ECAOB, it is also characterized by voluminous Phanerozoic granitoids with rich mineralisations. Thus, a brief comparison of their isotopic signatures with those of the ECAOB appears interesting for the understanding of their respective crustal development. Cathaysia has been considered as the easternmost part of the Tethyside orogen (Hsu et al 1990;
Sengör et al 1993). Cathaysia and the ECAOB are situated to the south and north of the Sino-Korean craton, respectively, and they exhibit very contrasting tectonic styles and crustal evolutions. The principal characteristics and differences between the Altaid and Cathaysia orogens are summarized in table 1. A-type granites also occur in Cathaysia (Xu et al 1992), but their Nd isotopic signatures are generally "crustal" (Martin et al 1994; Charoy and Raimbault 1994; Darbyshire and Sewell 1997). Most granitic rocks in SE China were produced by remelting of Proterozoic crustal sources; only very few granitic bodies in coastal Fujian and Taiwan have witnessed a greater contribution of the depleted mantle component in their magma genesis (Jahn et al 1976, 1986, 1990; Huang et al 1986; Lan et al 1995; Gilder et al 1996; Chen and Jahn 1998).

Figure 10 summarizes the $\mathrm{Nd}$ isotopic features of Phanerozoic granites from the Cathaysia orogenic belt and the Yangtze craton in comparison with those from the southern belt of the ECAOB. The isotopic distinction is very clear, suggesting that the Altaid granitoids represent an immense juvenile crustal addition, whereas Cathaysian granitoids are mainly reworked ancient crust, implying little net crustal growth.

\section{Conclusions}

- The vast orogenic belt (ECAOB) that welded together the Siberian and Sino-Korean cratons is characterized by voluminous granitic rocks of Paleozoic to Mesozoic ages. New Sr-Nd isotopic data and published isotopic and geochemical results show that abundant granitic rocks from the southern belt

Table 1. Comparison of crustal evolution between the ECAOB and SE China.

\begin{tabular}{lll}
\hline & East-Central Asia (Altaid) & SE China (Cathaysia) \\
\hline Type of orogen & Altaid (accretionary*) & Tethyside (collisional*) \\
Characteristics & Immense Phanerozoic granitic intrusions & Immense Phanerozoic granitic intrusions \\
Period of intrusion & 550 to 150 (possibly 120$) \mathrm{Ma}$ & $400(?)$ to $80 \mathrm{Ma}$ \\
& $\Delta \mathrm{T} \approx 400 \mathrm{Ma}$ & $\Delta \mathrm{T} \approx 300 \mathrm{Ma}$ \\
Total volume & $\approx 5.3 \mathrm{M}$ sq. km** $\approx 11 \%$ of total Asia) & not estimated \\
Granitic type & mainly I- and A-types & mainly S-type (I, A, M subordinate) \\
& Alkaline and peralkaline granites dominate & CA granites dominate \\
Crustal type & mainly juvenile & mainly reworked \\
$\mathrm{e}_{\mathrm{Nd}}(\mathrm{T})$ & +7 to +1 & -2 to -17 \\
Tectonics & Assembly of numerous arc complexes; & Assembly of ancient continental blocks; \\
& intruded by vast granitic plutons and & vast granitic plutons formed by remelting \\
of old basement rocks
\end{tabular}

Note: *Terminology of Windley $(1993,1995)$.

**According to Sengör et al (1993); controversial. 


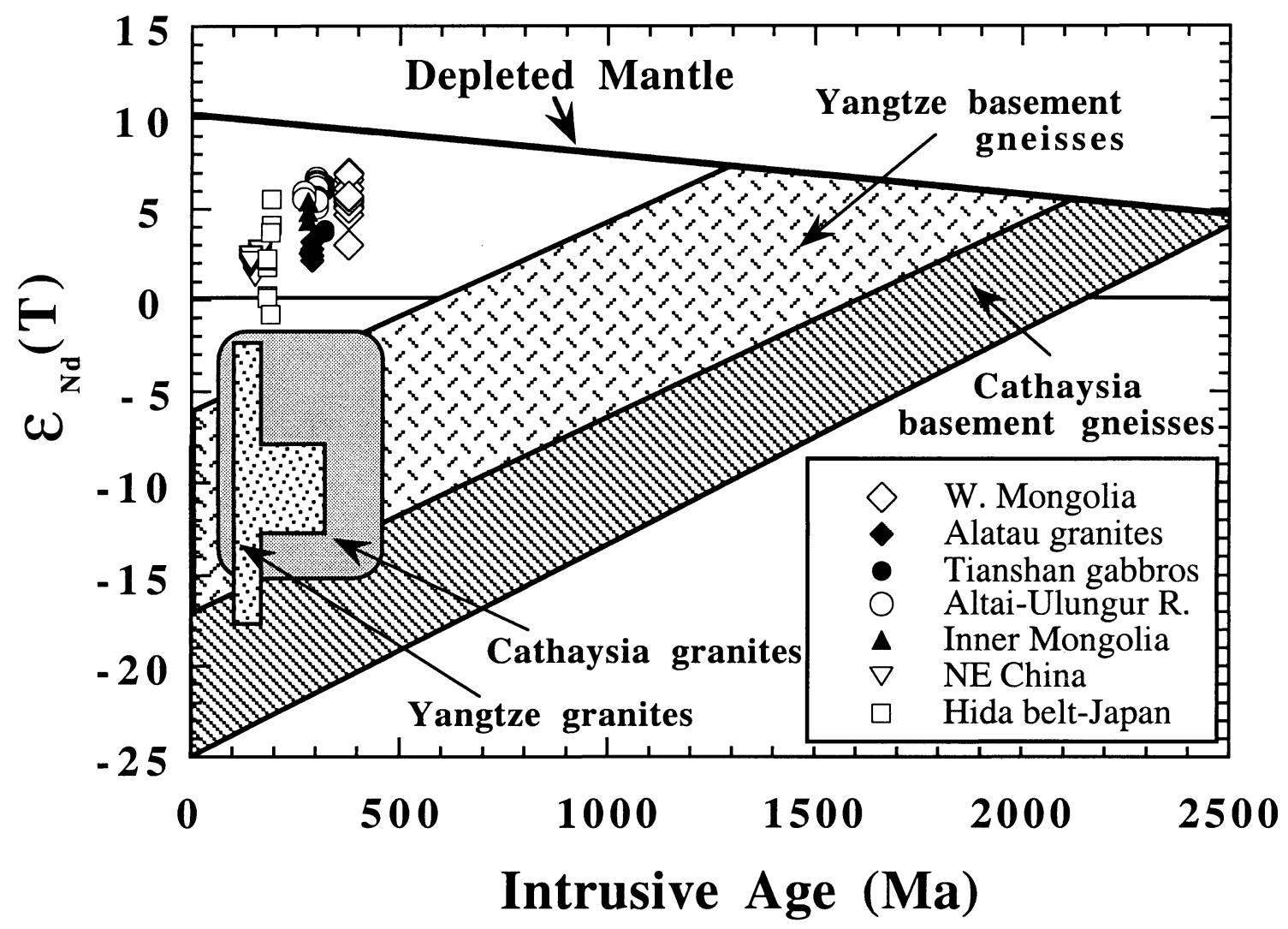

Figure 10. Comparison of granitic rocks from the Altaids (ECAOB) and Yangtze-Cathaysia in SE China. The granitoids from both orogenic belts were emplaced during approximately the same period (ca. 400 to $100 \mathrm{Ma}$ ) but were generated from very different source rocks as shown by the contrasting $\varepsilon_{\mathrm{Nd}}(\mathrm{T})$ values. The Yangtze-Cathaysia granites were mainly formed by remelting of Precambrian basement rocks with little contribution from the upper mantle, except for the Cretaceous granitic rocks of coastal Fujian and Taiwan. Data for Cathaysia are from the compilation of Chen and Jahn (1998).

Table 2. Phanerozoic juvenile crustal growth.

Arc magmatism (Reymer and Schubert 1984)

(Canadian Cordillera and Altaid Collage excluded)

Canadian Cordillera

$\left(\Delta \mathrm{T}=350 \mathrm{Ma} ; \approx 1\right.$ million $\left.\mathrm{km}^{2}\right)$

(Samson et al 1989)

Altaid Collage $\left(\Delta \mathrm{T}=400 \mathrm{Ma} ; \approx 2\right.$ million $\left.\mathrm{km}^{2}\right)$ (Sengör et al 1993)

Total Phanerozoic growth rate

$$
\begin{aligned}
& \approx 0.30 \mathrm{~km}^{3} / \mathrm{a} \\
& \approx 1.55 \mathrm{~km}^{3} / \mathrm{a}
\end{aligned}
$$

For comparison:

Birimian terranes $(\approx 2.1 \mathrm{Ga} ; \Delta \mathrm{T}=120 \mathrm{Ma})$

Outcrop $=$ W. Africa $\left(0.9\right.$ million $\left.\mathrm{km}^{2}\right)$

+ Guyana (0.3 million $\left.\mathrm{km}^{2}\right)$

+ possible extension $\approx 3$ million $\mathrm{km}^{2}($ total $)$

Growth rate (Boher et al 1992)

$\approx 1.6 \mathrm{~km}^{3} / \mathrm{a}$

(overestimated?)

Arabian-Nubian Shield ( $\Delta \mathrm{T} \approx 300 \mathrm{Ma} ; 900-600 \mathrm{Ma})$

Growth rate

(similar to that of the Canadian Cordillera)

of the ECAOB (Xinjiang-western Mongolian-inner Mongolia-NE China) possess un-ambiguous isotopic characteristics for juvenile crust $\left(\mathrm{I}_{\mathrm{Sr}} \approx 0.702\right.$ to $0.707 ; \varepsilon_{\mathrm{Nd}}(\mathrm{T})=+7$ to +1$)$. This is also true for Phanerozoic granitoids from Mongolia and Trans- baikalia. Oxygen isotopic data for granitic rocks from Transbaikalia also support a significant mantle input, particularly for those emplaced during the Permian or later (Wickham et al 1995, 1996). Consequently, the ECAOB represents probably the most important mass transfer from the mantle to the continental crust in Phanerozoic times.

- The origin of A-type granites has long been controversial, and A-type granites seem to have multiple origins. Most of the post-orogenic A-type granites from the ECAOB are demonstratably of predominantly mantle origin based on their Nd-Sr isotopic data. The mantle origin involves a two-stage process, with a basaltic rock or magma as the immediate protolith of the A-type granite through partial melting or fractional crystallisation, respectively.

- The tectonic evolution of the ECAOB (or Altaid Collage) is most probably related to the accretion of arc complexes and the emplacement of juvenile crust as suggested by Sengör et al (1993). This idea is generally compatible with the available $\mathrm{Sr}-\mathrm{Nd}-\mathrm{O}$ isotopic data. However, the emplacement of voluminous post-orogenic A-type granites requires an additional process, probably involving basalt underplating from mantle plume partial melting and followed by extensive fractional crystallisation. If 
the volume of the basaltic protoliths is considered, the juvenile material of the Altaid Collage separated from the upper mantle would be much greater than the total mass of the granitoids presently observed. It appears that intraplate magmatism involving plume melting, basalt underplating, differentiation or remelting of a basaltic source, is an important process of continental growth in the Phanerozoic.

- For the entire Altaid Collage, Sengör et al (1993) estimated that during the $400 \mathrm{Ma}$ of crustal evolution, a total area of about two million $\mathrm{km}^{2}$ of juvenile crust was added to Asia. This is translated into a growth rate of about $0.3 \mathrm{~km}^{3} / \mathrm{a}$. Combining this with the growth rate of the Canadian Cordillera (about $0.15 \mathrm{~km}^{3} / \mathrm{a}$, Samson et al 1989; Samson and Patchett 1991), the combined would be at least $50 \%$ higher than the global growth rate of ca. $1.1 \mathrm{~km}^{3} /$ a deduced from arc magmatism by Reymer and Schubert $(1984,1986)$. Consequently, the recent "discovery" of juvenile crust in several Phanerozoic orogenic belts, in particular the ECAOB, may considerably change our views of continental growth.

\section{Acknowledgements}

This paper is dedicated to the retirement of Prof. K. Gopalan. Laboratory assistance of J. Cornichet, O. Henin and J. Macé is deeply appreciated. We have benefitted from constructive comments of Nick Arndt, R. Capdevila and S. Fourcade on an early version of this paper. The research work of Dawei Hong in Xinjiang and inner Mongolia was supported by the National Natural Science Foundation of China and the Foundation of Geological Sciences of China. Fuyuan $\mathrm{Wu}$ acknowledges the support of the Chinese Government and the hospitality of the Geochemistry Group (Géosciences Rennes) during his stay in Rennes. Alfred Kröner (Mainz) and Scott Samson (Syracuse) provided constructive comments and suggestions for improving the final draft. This research was supported by the INSU-CNRS through the Programme "Dynamique des Transferts Terrestres" (1997-1998). This is INSU contribution no. xxx. This is also a contribution to IGCP-420: Crustal Growth in the Phanerozoic: Evidence from East-Central Asia.

\section{References}

Anderson J L and Morrison J 1992 The role of anorogenic granites in the Proteorozic crustal development of North America. In: Proterozoic Crustal Evolution (ed) K C Condie, Amsterdam: Elsevier, 263-299

Arakawa Y and Shimura T $1995 \mathrm{Nd}-\mathrm{Sr}$ isotopic and geochemical characteristics of two contrasting types of calc-alkaline plutons in the Hida belt; Japan. Chem. Geol. 124 217-232

Armstrong R L 1968 A model for $\mathrm{Sr}$ and $\mathrm{Pb}$ isotope evolution in a dynamic earth; Rev. Geophys. 6 175-199
Armstrong R L 1981 Radiogenic isotopes: The case for crustal recycling on a near-steady state no-continental-growth earth; Phil. Trans. Royal Soc. London, A $301443-472$

Armstrong R L 1991 The persistent myth of crustal growth; Australia J. Earth Sci. 38 613-630

Arndt N T and Goldstein S L 1987 Use and abuse of crustformation ages; Geology 15 893-895

Bernard-Griffiths J, Peucat J J, Sheppard S and Vidal P 1985 Petrogenesis of Hercynian leucogranites from the southern Armorican Massif: contribution of REE and isotopic (Sr, Nd, $\mathrm{Pb}$, and $\mathrm{O}$ ) geochemical data to the study of source rock characteristics and ages; Earth Planet. Sci. Lett 74 235-250

Boher M, Abouchami W, Michard A, Albarède F and Arndt NT 1992 Crustal growth in West Africa at $2.1 \mathrm{Ga}$; J. Geophys. Res. 97 345-369

Charoy B and Raimbault L 1994 Zr-, Th- and REE-rich biotite differentiates in the A-type granites pluton of Suzhou (eastern China): the key role of fluorine; J. Petrology 35 919-962

Chen J F and Jahn B M 1998 Crustal evolution of southeastern China: Nd and $\mathrm{Sr}$ isotopic evidence; Tectonophysics $\mathbf{2 8 4}$ 101-133

Chen J F, Man F S and Ni S B 1995 Nd and Sr isotopic geochemistry of mafic-ultramafic intrusions from Qinbulake, West Tianshan Mountain, Xinjiang; Geochimica 24 121127 (in Chinese with English abstract)

Cluzel D 1991 Late Palaeozoic to early Mesozoic geodynamic evolution of the circum-Pacific orogenic belt in South Korea and Southwest Japan; Earth Planet Sci. Lett. 108 289-305

Cocherie A, Rossi Ph, Fouillac A M and Vidal Ph 1994 Crust and mantle contributions to granite genesis: An example from the Variscan batholith of Corsica, France, studied by trace-element and Nd-Sr-O isotope systemetics; Chem. Geol. $115173-211$

Coleman R G 1989 Continental growth of northwest China; Tectonics 8 621-635

Collins W J, Beams S D, White A J R and Chappell B W 1982 Nature and origin of A-type granites with particular reference to southeastern Australia; Contrib. Mineral. Petrol. 80 189-200

Costa S and Rey P 1995. Lower crustal rejuvenation and growth during post-thickening collapse: Insights from a crustal cross section through a Variscan metamorphic core complex; Geology 23 905-908

Creaser R A, Price R C and Wormald R J 1991 A-type granites revisited: assessment of a residual-source model; Geology 19 $163-166$

Darbyshire D P F, Sewell R J 1997 Nd and Sr isotope geochemistry of pjutonic rocks from Hong Kong: implications for granite petrogenesis, regional structure and crustal evolution; Chem. Geol. 143 81-93

DePaolo D J 1981 A neodynium and strontium isotopic study of the Mesozoic calc-alkaline granitic batholiths of the Sierra Nevada and Peninsular Ranges, California; J. Geophys. Res. 86 10470-10488.

Downes H, Shaw A, Williamson B J and Thirlwall M F 1997 $\mathrm{Sr}, \mathrm{Nd}$ and $\mathrm{Pb}$ isotope geochemistry of the Hercynian granodiorites and monzogranites, Massif Central, France; Chem. Geol. 136 99-122

Eby G N 1992 Chemical subdivision of the A-type granitoids: petrogenetic and tectonic implications; Geology 20 641-644

Foland K A and Allen J C 1991 Magma sources for Mesozoic anorogenic granites of the White Mountain magma series, New England, U.S.A.; Contrib. Mineral. Petrol. 109 195211

Gilder S A, Gill J, Coe R S, Zhao X, Liu Z, Wang G, Yuan K, Liu W, Kuang G and Wu H 1996 Isotopic and paleomagmatic constraints on the Mesozoic tectonic evolution of south China; J. Geophys. Res. 101 16137-16154 
Gruschka S, Kröner A, Avdeev A V, Seitov N S, Oberhänsli R 1997 Early Palaeozoic accretion of arcs and microcontinents in the Central Asian Mobile Belt of southern Kazakhstan as deduced from $\mathrm{Pb}-\mathrm{Pb}$ zircon and $\mathrm{Sm}-\mathrm{Nd}$ model ages; Terra Nova 9 Abstract Supplement 1, 340

Han B F, Wang S G, Jahn B M, Hong D W, Kagami H and Sun Y L 1997 Depleted-mantle magma source for the Ulungur River A-type granites from north Xinjiang, China: geochemistry and $\mathrm{Nd}-\mathrm{Sr}$ isotopic evidence, and implication for Phanerozoic crustal growth; Chem Geol. 138 135-159

Hirooka K, Nakajima T, Sakai H, Date T, Nittamachi K and Hattori I 1983 Accretion tectonics inferred from paleomagnetic measurements of Paleozoic and Mesozoic rocks in central Japan. In: Accretion Tectonics in the Circum-Pacific Regions. M Hashimoto and S Uyeda (eds); Tokyo: Terra Sci. Publ. Co., 179-194

Hong D W, Huang H Z, Xiao Y J, Xu H M and Jin M Y, 1995 Permian alkaline granites in central inner Mongolia and their geodynamic significance; Acta Geologica Sinica 8 27-39

Hong D W, Wang S G, Han B F and Jin M Y 1996 Postorogenic alkaline granites from China and comparisons with anorogenic alkaline granites elsewhere; J. SE Asian Earth Sci. 13 13-27

Hsü K J, Li J L, Chen H H, Wang Q C, Sun S and Sengör A M C 1990 Tectonics of South China: key to understanding west Pacific geology; Tectonophysics 183 9-39

Hu A Q, Jahn B M, Zhang G, Zhang Q 2000a Crustal evolution and Phanerozoic crustal growth in Northern Xinjiang: Nd-Sr isotopic evidence. Part I: Isotopic characterization of basement rocks. (in preparation).

Hu A Q, Jahn B M, Zhang G, Zhang Q 2000b Crustal evolution and Phanerozoic crustal growth in Northern Xinjiang: Nd-Sr isotopic evidence. Part II: Phanerozoic granite intrusions (in preparation).

Huang X, Sun S H, DePaolo D J and Wu K L 1986 Nd-Sr isotope study of Cretaceous magmatic rocks from Fujian province; Acta Petrol. Sinica 2 50-63

Jahn B M, Chen P Y and Yen T P 1976 Rb-Sr ages of granitic rocks in southeastern China and their tectonic significance; Bull. Geol. Soc. Am. 86 763-776

Jahn B M, Martineau F, Peucat J J and Cornichet J 1986 Geochronology of the Tananao Schist complex, Taiwan, and its regional tectonic significance; Tectonophysics 125 103-124

Jahn B M, Zhou X H and Li J L 1990 Formation and tectonic evolution of southeastern China and Taiwan: Isotopic and geochemical constraints; Tectonophysics 183 145-160

Javoy M and Weiss D 1987 Oxygen isotopic composition of alkaline anorogenic granites as a clue to their origin: the problem of crustal oxygen; Earth Planet. Sci. Lett. 84 415-422

Jin C W and Zhang X Q 1993 A geochronology and genesis of the western Junggar granitoids, Xinjiang, China; Scientia Geologica Sinica $28 \quad 28-36$ (in Chinese with English abstract).

Kononova V A, Pervov V A, Bogatikov O A, Upton B G J, Suddaby P and Woolley A R 1996 Geochemical constraints on the petrogenesis of the high-K rocks of the southern Sakun Massif, Aldan Shield, Siberia; J. Conf. Abst. 1324

Kovalenko V I, Tsareva G M, Yarmolyuk V V, Troisky V A, Farmer G L and Chernishev I V 1992 Sr-Nd isotopic compositions and the age of rare-metal peralkaline granitoids from western Mongolia; Dokladi Akad. Nauk 237 570-574 (in Russian)

Kovalenko V, Yarmolyuk V and Bogatikov O 1995 Magmatism, geodynamics, and metallogeny of Central Asia. Miko Moscow: Commercial Herald Publishers 272 pp.

Kovalenko V I, Yarmolyuk V V, Kovach V P, Kotov A B, Kozakov I K, Sal'nikova E B 1996 Sources of Phanerozoic granitoids in Central Asia: Sm-Nd isotope data; Geochem. Int'l. 34 628-640
Kuzmin M I and Antipin V S 1993 Geochemical types of granitoids of the Mongol-Okhotsk belt and their geodynamic settings; Chinese J. Geochim. 12 110-117

Kwon S T, Tilton G R, Coleman R G and Feng Y 1989 Isotopic studies bearing on the tectonics of the west Junggar region, Xinjiang, China; Tectonics 8 719-727

Lan C Y, Lee T, Jahn B M and Yui T F, 1995 Taiwan as a witness of repeated mantle inputs-Sr-Nd-O isotopic geochemistry of Taiwan granitoids and metapelites; Chem. Geol. 124 287-303

Landenberger B and Collins W J 1996 Derivation of A-type granites from a dehydrated charnocktic lower crust: evidence from the Chaelundi Complex, eastern Australia; J. Petrology 37 145-170

Litvinovsky B A, Zanvilevich A N, Alakshin A M and Podladchikov Yu 1992 The Angara-Vitim batholith-the largest granitoid pluton. Novosibirsk; Nauka 141 pp.

Martin H, Bonin B, Capdevila R, Jahn B M, Lamayre J and Wang Y, 1994 The Kuiqi peralkaline granitic complex (SE China): petrology and geochemistry; J. Petrology 35 983-1015

Mizutani S and Hattori I 1983 Hida and Mino: Tectonostratigraphic terranes in central Japan. In: Accretion Tectonics in the Circum-Pacific Regions. M Hashimoto and S Uyeda (eds), Tokyo: Terra Sci. Publ. Co. 169-178

Moorbath S 1978 Age and isotopic evidence for the evolution of continental crust; Phil. Trans. R. Soc. London 288 401-413

Poitrasson F, Duthou J L and Pin C 1995 The relationship between petrology and $\mathrm{Nd}$ isotopes as evidence for contrasting anorogenic granite genesis: example of the Corsican Province (SE France); J. Petrol. 36 1251-1274

Reymer A and Schubert G 1984 Phanerozoic addition rates to the continental crust and crustal growth. Tectonics; 3 63-77

Reymer A and Schubert G 1986 Rapid growth of some major segments of continental crust; Geology 14 299-302

Rudnick R L and Fountain D M 1995 Nature and composition of the continental crust: a lower crustal perspective; Reviews Geophys. 33 267-309

Samson S D 1998 Phanerozoic crustal growth in North America: A Cordilleran and Appalachian perspective. IGCP-420 Workshop, Xinjiang, [abstract] (in press).

Samson S D and Patchett P J 1991 The Canadian Cordillera as a modern analogue of Proterozoic crustal growth; Aust. Jour. Earth Sci. 38 595-611

Samson S D, McClelland W C, Patchett P J, Gehrels G E, Anderson R G 1989 Evidence from neodymium isotopes for mantle contributions to Phanerozoic crustal genesis in the Canadian Cordillera; Nature 337 705-709

Sengör A M C, Natal'in B A and Burtman V S 1993 Evolution of the Altaid tectonic collage and Paleozoic crustal growth in Eurasia. Nature; 364 299-307, 1993

Sengör A M C and Natal'in B A 1996 Turkin-type orogeny and its role in the making of the continental crust; Annu. Rev. Earth Planet. Sci. 24 263-337

Stein M and Hofmann A W 1994 Mantle plumes and episodic crustal growth; Nature 372 63-68

Taylor S R and McLennan S M 1985 The continental crust: its composition and evolution. (Blackwell) 312 pp. 1985

Taylor S R and McLennan S M 1995 The geochemical evolution of the continental crust; Rev. Geophysics 33 241-265

Turner S P, Foden J D and Morrison R S 1992 Derivation of A-type magmas by fractionation of basaltic magma: an example from the Padthaway Ridge, South Australia; Lithos 28 151-179

Vidal P, Bernard-Griffiths J, Cocherie A, Le Fort P, Peucat J J and Sheppard S 1984 Geochemical comparison between Himalayan and Hercynian leucogranites; Phys. Earth Planet. Interiors 35 179-190 
Wang S G, Han B F, Hong D W, Xu B L and Sun Y L 1994 Geochemistry and tectonic significance of alkali granites along Ulungur River, Xinjiang (in Chinese with English abstract); Scientia Geologica Sinica 29 373-383

Whalen J B, Currie K L and Chappell B W, 1987 A-type granites: geochemical characteristics, discrimination and petrogenesis; Contrib. Mineral. Petrol. 95 407-419

Whalen J B, Jenner G A, Longstaff F J, Robert F and Galiépy C 1996 Geochemical and isotopic (O, Nd, $\mathrm{Pb}$ and $\mathrm{Sr})$ constraints on A-type granite petrogenesis based on the Topsails igneous suite, Newfoundland Appalachians; J. Petrology 37 1463-1489

Wickham S M, Litvinovsky B A, Zanvilevich A N and Bindeman I N 1995 Geochemical evolution of Phanerozoic magmatism in Transbaikalia, East Asia: a key constraint on the origin of K-rich silicic magmas and the process of cratonization; J. Geophys. Res. 100 15641-15654

Wickham S M, Alberts A D, Zanvilevich A N, Litvinovsky B A, Bindeman I N and Schuble E A 1996 A stable isotope study of anorogenic magmatism in East Central Asia; J. Petrology 37 1063-1095

Windley B 1993 Proterozoic anorogenic magmatism and its orogenic connections; J. Geol. Soc. London 150 39-50
Windley B 1995, The Evolving Continent, 3rd edition. (Chichester: John Wiley \& Sons) 526 pp.

Wu F Y, Jahn B M, Lin Q, Ge WC and Sun D Y 2000 Highly fractionated I-type granites from NE China: geochemistry, petrogenesis and implications for continental growth. (to be submitted to J. Petrology)

Xu K Q, Zhu J C, Liu C S, Shen W Z and Xu S J 1992 Genetic series and material sources of granitoids in South China. In: Petrogenesis and Mineralisation of Granitoids. G Z Tu, K Q Xu and Y Z Qiu (eds), Beijing: Science Press 3-22

Zanvilevich A N, Litvinovsky B A and Wickham S M 1995 Genesis of alkaline and peralkaline syenite-granite series: the Kharitonovo pluton (Transbaikalia, Russia); J. Geol. 103 $127-145$

Zhao Z H 1993 REE and O-Pb-Sr-Nd isotopic compositions and petrogenesis of the Altai granitoids. In: New Development of Solid Earth Science in Northern Xinjiang. Beijing: Science Publishing Co., 239-266

Zhou T X, Chen J F, Chen D G and Li X M 1995 Geochemical characteristics and genesis of granitoids from Alataw Mountain, Xinjiang, China; Geochimica 24 32-42 (in Chinese with English abstract). 